\title{
A large new mosasaur from the Upper Cretaceous of The Netherlands
}

\author{
Rudi W. Dortangs ${ }^{1}$, Anne S. Schulp ${ }^{1,2}$, Eric W.A. Mulder ${ }^{3}$, John W.M. Jagt ${ }^{1}$, \\ Hans H.G. Peeters ${ }^{1}$ \& Douwe Th. de Graaf ${ }^{1}$ \\ ${ }^{1}$ Natuurhistorisch Museum Maastricht, PO Box 882, NL 6200 AW Maastricht, \\ The Netherlands. \\ 2 corresponding author; e-mail: mail@nhmmaastricht.nl \\ 3 Museum Natura Docet, Oldenzaalsestraat 39, NL 7591 GL Denekamp, \\ The Netherlands.
}

Manuscript received: December 2001; accepted: March 2002

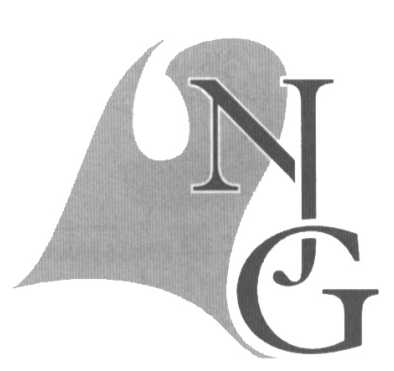

\begin{abstract}
We report the discovery of a new species of marine reptile, a mosasaur, from the Upper Cretaceous (Maastrichtian) of The Netherlands. Prognathodon saturator sp. nov. is represented by an almost complete skull and much of the postcranial skeleton, and is one of the largest mosasaurs discovered to date. The stout skull and extremely massive jaws are more powerfully built than in any other known mosasaur. Bite marks, the partial disarticulation and scattering of the skeleton, and the presence of associated teeth of Squalicorax and Plicatoscyllium suggest extensive scavenging by sharks.
\end{abstract}

Keywords: Mosasaurs, Prognathodon, Maastrichtian, Upper Cretaceous, The Netherlands.

\section{Introduction}

Mosasaur remains have been known as rare discoveries from the Maastrichtian type area since 1766 (Bardet \& Jagt, 1996). Historically, these fossils played an important part in the development of the concept of extinction by the French anatomist Baron G. Cuvier. Other reptiles known from the Maastrichtian type area include plesiosaurs, crocodiles, turtles and dinosaurs (Mulder et al., 1998). This, combined with an excellent stratigraphic control and the generally superb state of preservation of its vertebrate fossils, has made the Maastrichtian type area a classic site in the history of palaeontology. Despite the everincreasing collecting efforts of a large group of amateur palaeontologists around Maastricht, discoveries of articulated mosasaur material from the type Maastrichtian remain extremely rare.

Here we describe the partial skeleton of the first reasonably complete mosasaur to be reported from the
Maastricht area since 1957 (Kruytzer, 1957). The specimen was discovered by one of the authors (RWD) in the calcarenites of the upper Lanaye Member (Gulpen Formation, Late Maastrichtian, Belemnitella junior Cephalopod Zone) at the ENCI-Maastricht B.V. quarry (Fig. 1), south of the city of Maastricht, and adjacent to the type section of the Maastrichtian Stage (Schiøler et al., 1997). Strontium-isotope curve fitting (Vonhof \& Smit, 1996) suggests an age of 66,1 million years (Ma). The specimen includes an almost complete skull, the greater portion of the neck and trunk, elements of the pectoral girdle and the forelimb, and 12 disarticulated pygal and caudal vertebrae. A fair number of shed shark teeth were discovered associated with the skeleton, and several elements display post-mortem shark bite marks.

\section{Description}

Mosasaur genera known from the Maastricht area so far included Mosasaurus, Leiodon, Carinodens, Plate- 


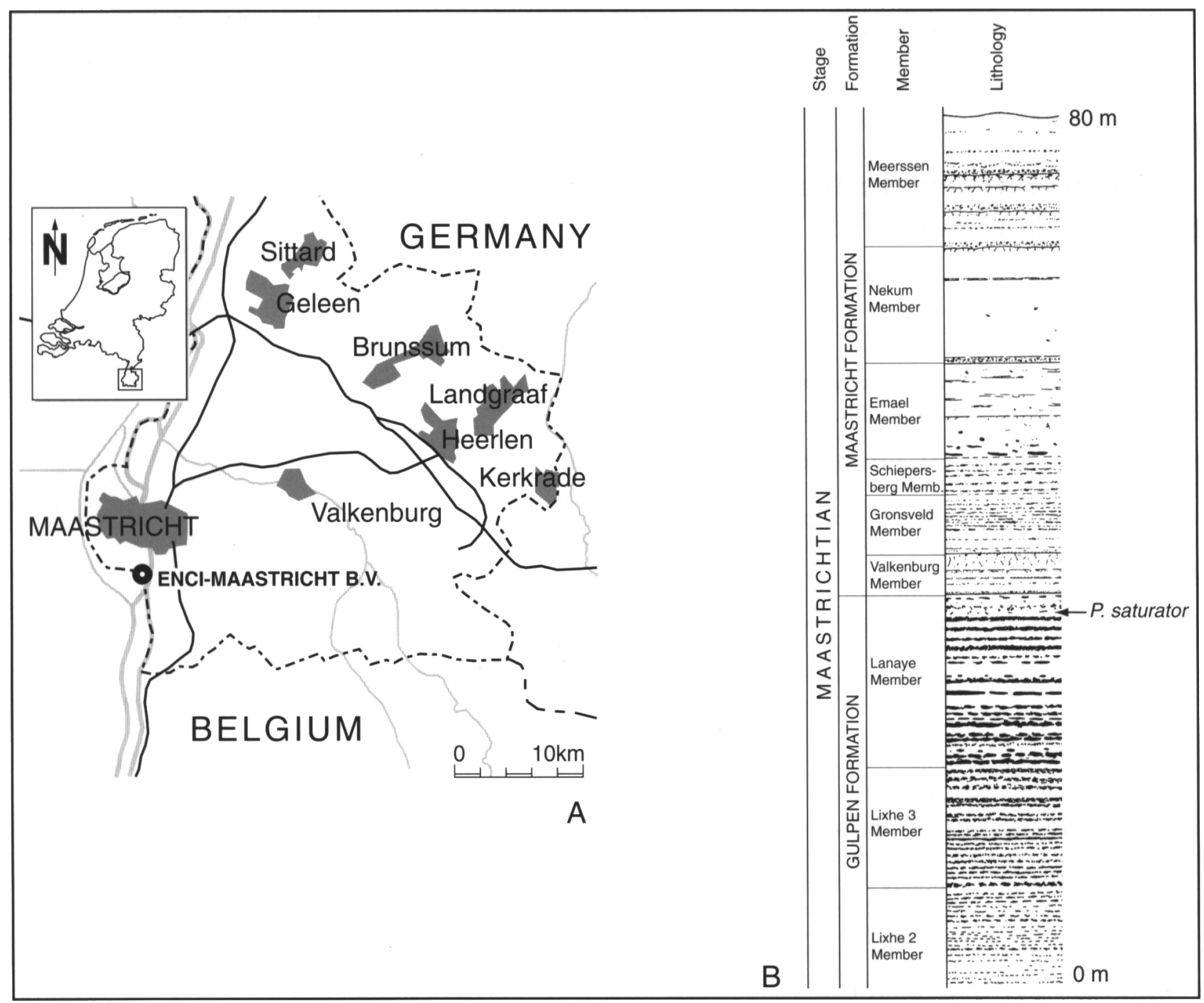

Fig. 1. Location of the ENCI-Maastricht B.V. quarry, $3 \mathrm{~km}$ south of the city of Maastricht, The Netherlands (A) and stratigraphic position of the specimen $(\mathrm{B})$.

carpus and Plioplatecarpus (Kuypers et al., 1998). We refer the present discovery to the genus Prognathodon, making it the first unambiguous record of this genus from the Maastrichtian type area. Several autapomorphies distinguish this specimen from previously described species of Prognathodon, leading us to designate a new species:

\section{Prognathodon saturator sp. nov.}

Etymology

saturator (Latin): he who gives satisfaction (both to Maastrichtian sharks as well as Recent palaeontologists).

\section{Holotype}

NHMM 1998141 (collections of Natuurhistorisch Museum.Maastricht, The Netherlands).

\section{Locality}

ENCI-Maastricht B.V. quarry, $3 \mathrm{~km} \mathrm{~S}$ of Maastricht, The Netherlands $\left(50^{\circ} 49^{\prime} \mathrm{N}\right.$ latitude, $5^{\circ} 41^{\prime} \mathrm{E}$ longitude).

\section{Material}

Near-complete skull, articulated cervical and anterior dorsal vertebrae with cervical and dorsal ribs, isolated pygal and caudal vertebrae, scapula-coracoid and scattered elements of appendicular skeleton.

\section{Diagnosis}

A large and massively built mosasaur. Quadrate massive, lacking the ala ridge dorsolaterally on the anterior face of the ala and the thin, high crest on the dorsal median ridge, found in other members of the genus. Dentaries relatively tall with a prominently concave dorsal dental margin. Ventral margin of maxilla slightly convex. Zygosphenes and zygantra present. 


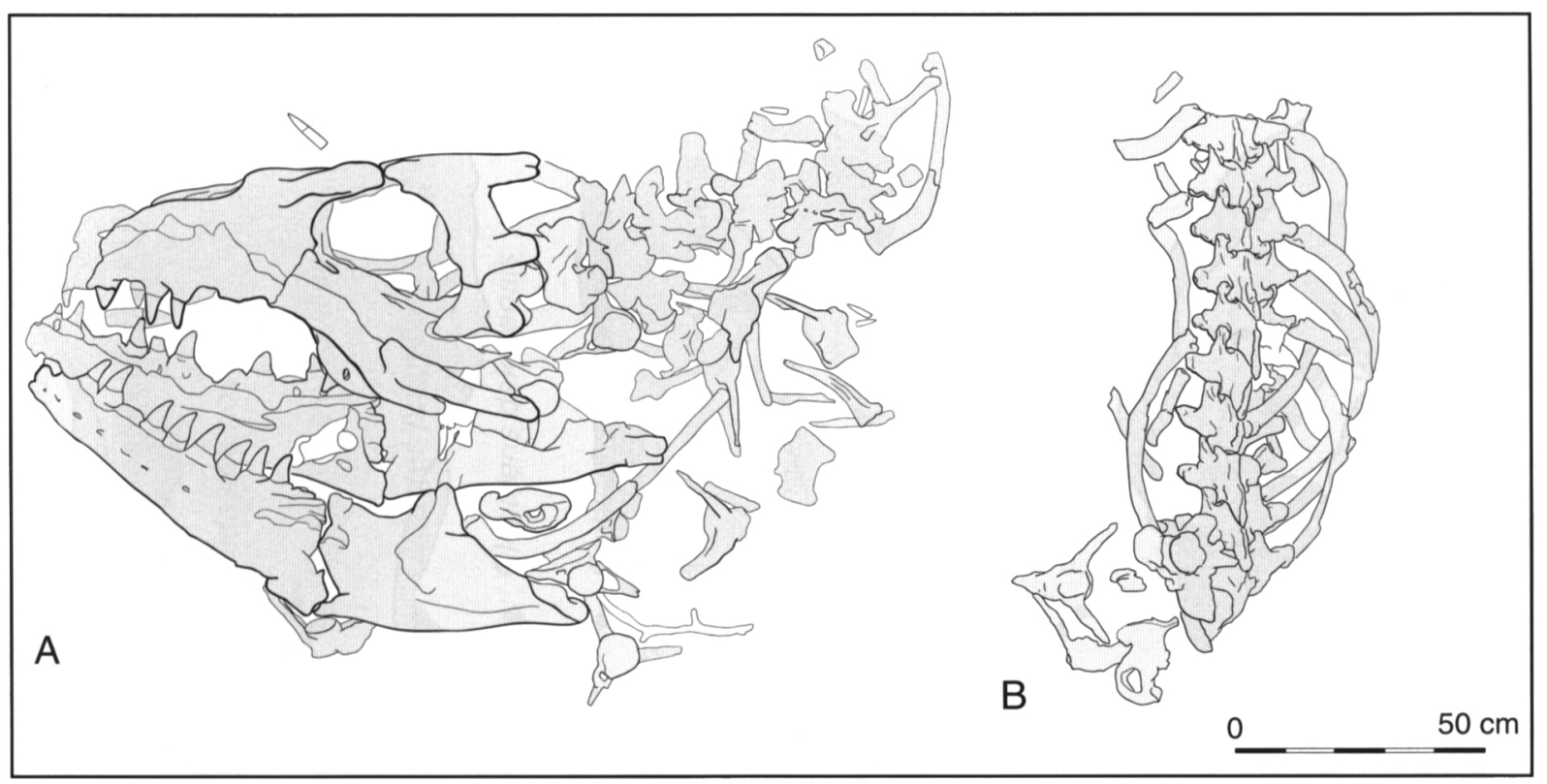

Fig. 2. Prognathodon saturator $\mathrm{sp}$. nov. (NHMM 1998141). (A) Skull with cervical vertebrae.

(B) Dorsal vertebrae (Rogier Trompert Medical Art).

\section{Description}

The skull (Fig. 2A) is near-complete with the exception of the anterior portions of the premaxilla and the dentaries, which have been lost during quarrying prior to the discovery. Although most of the anterior marginal teeth are missing, the inclination of the preserved roots of the first and second dentary teeth suggests that $P$. saturator had procumbent teeth, a condition similar to $P$. solvayi (Lingham-Soliar \& Nolf, 1990). The dorsal margin of the dentary is concave; the ventral margin of the maxilla is slightly convex. The marginal teeth are massive, and generally smooth and rounded, as opposed to the facetted and laterally compressed teeth in most other mosasaurs. The mandible is extremely tall and massive, even more so than those of other members of the genus. The equally massive pterygoid contains 6 large, only moderately recurved teeth. The well-preserved left quadrate (Fig. 3 ) is robust. The greater part of the skull roof is pre- served, with only the left side of the wide temporal arcade missing. The temporal region and braincase are all very stout compared to other species of Prognathodon. Both the cervical and dorsal vertebrae (Fig. 2A, B) have large and functional zygosphene-zygantrum complexes. The almost completely preserved scapula and coracoid are tightly fused. Characters shared with other members of the genus include the low number of teeth in comparison to other mosasaurs (14 dentary, probably 12 maxillary, 6 pterygoid); pterygoid teeth almost of equal size to marginal teeth and the fusion of the suprastapedial and infrastapedial processes on the quadrate.

\section{Phylogenetic analysis}

Phylogenetic analysis confirms the new species' position within Prognathodon (Fig. 4 and Table 1). Synapomorphies supporting inclusion in Mosasaurinae (as defined by Bell, 1997) include the presence of fused haemal arches; a prominent supraorbital process of

Table 1. Phylogenetic data, as added to Bell (1997).

\begin{tabular}{|c|c|c|c|c|c|c|c|c|c|}
\hline \multicolumn{10}{|c|}{ Prognathodon saturator (NHMM 1998141) } \\
\hline ??? 00 & ?? 110 & $? 1101$ & 01011 & 10111 & ??? 10 & $0000 ?$ & ??? 20 & ?? 111 & 01010 \\
\hline 10000 & 01100 & 00101 & ?? 3? ? & $2101 ?$ & $? 0100$ & 10100 & 01201 & $0 ? 10 ?$ & 01001 \\
\hline $2110 ?$ & ???01 & ??0?? & ? 1??? & ????? & ???2? & ????? & ????? & $? ?$ & \\
\hline \multicolumn{10}{|c|}{ Prognathodon solvayi (IRScNB R33) } \\
\hline $00 ? 00$ & 00110 & 00101 & 01010 & 10111 & $11 ? 10$ & $? 0005$ & $0 ? 120$ & ? 1111 & 01010 \\
\hline 01001 & 01000 & 001?? & ?? 41? & 20011 & 10100 & $? 000 ?$ & 01201 & ?? 10? & $0 ? 00 ?$ \\
\hline $2 ? 10 ?$ & ????? & ????? & ? $11 ? ?$ & ????? & ????? & ????? & ????? & ?? & \\
\hline
\end{tabular}




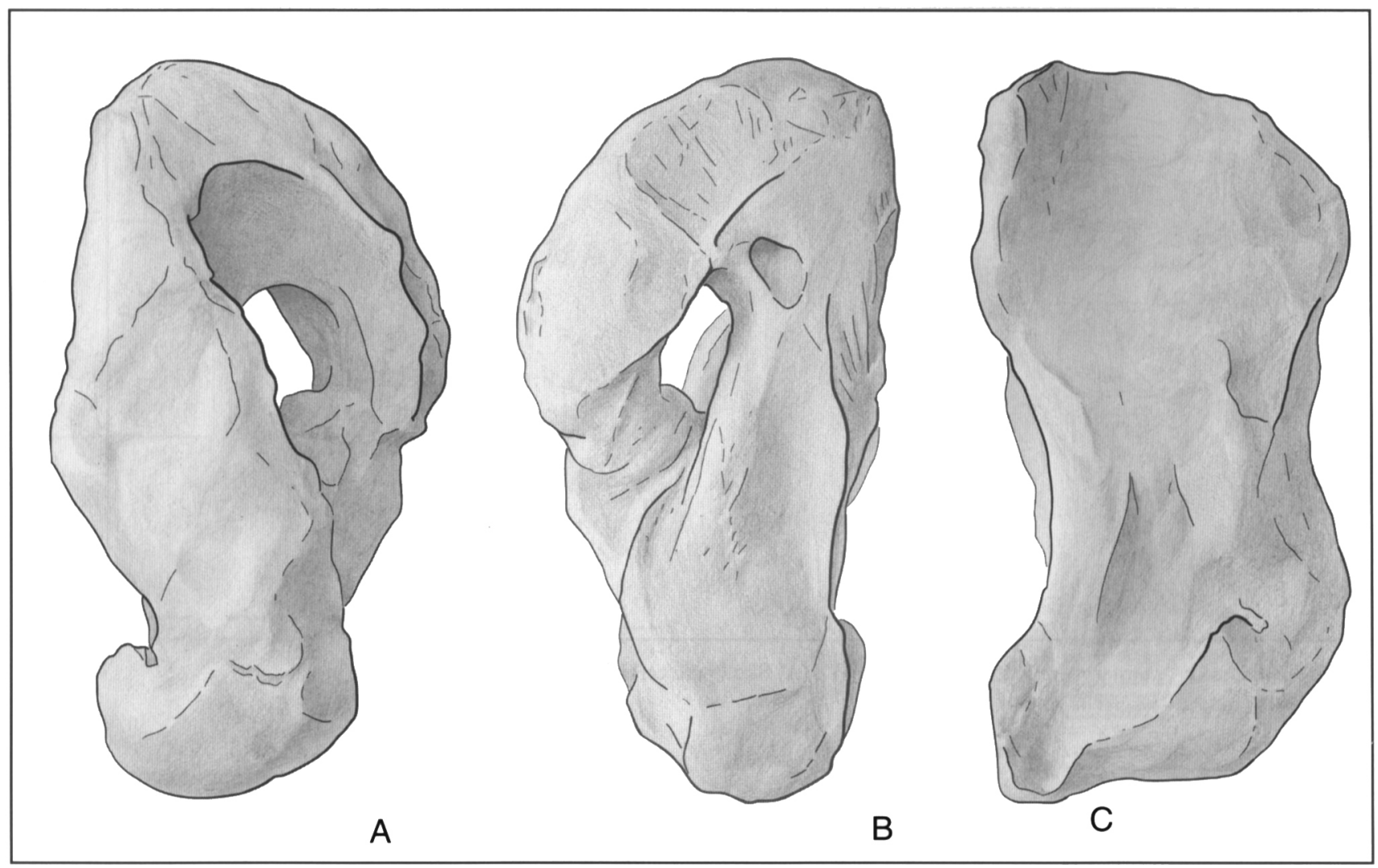

Fig. 3. Quadrate of Prognathodon saturator sp. nov. (NHMM 1998141) in frontal (A), lateral (B) and medial (C) view (Rogier Trompert Medical Art).

the prefrontal; the greatly expanded posterior wing of the coronoid; a high, thin surangular coronoid buttress and equidimensional condyles of anteriormost trunk vertebrae. Although haemal arches that are 1,5 times longer than neural arches of the same vertebra are considered a synapomorphy in Mosasaurinae (Bell, 1997), this condition is reversed in the present specimen with haemal arches barely longer than the neural arches. Synapomorphies linking the present specimen with Prognathodon and Plesiotylosaurus include anterior pterygoid teeth that approach the size of marginal teeth.

The analysis was based on the phylogenetic revision of the North American and Adriatic Mosasauroidea by Bell (1997), to which we added data on the specimen described here and on the holotype (IRScNB 33) of the Early Maastrichtian P. solvayi (see Lingham-Soliar \& Nolf, 1990). Three other species of Prognathodon, viz. $P$. waiparaensis, $P$ giganteus and $P$. stadtmani were not included in this analysis, because data available were too limited to warrant a meaningful comparison, but attribution of the present specimen to $P$. stadtmani, $P$. waiparaensis or P. giganteus can be excluded with confidence, on the following grounds. Prognathodon saturator may be differentiated from these congeners in being much larger than any previously recorded Prognathodon and generally being considerably more massive. The Early Campanian $P$. stadtmani (see Kass, 1999; Kass \& Smith, 2001) differs from $P$ saturator in having a much more slender dentary and coronoid and recumbent anteriormost dentary teeth. Prognathodon waiparaensis (see Welles \& Gregg, 1971) also differs from $P$. saturator in having a much more slender dentary, with a nearly straight dorsal dental margin and an elongate posterior mandibular unit inclined at almost $45^{\circ}$. Prognathodon giganteus (see Lingham-Soliar \& Nolf, 1990) can be distinguished from $P$. saturator by its straight dorsal dental margin, small coronoid, rectangular posterior mandibular unit with short and blunt retroarticular process and a considerably less massive quadrate.

Phylogenetic trees, rooted in Clidastes liodontus, were generated using PAUP* (Swofford, 2000) and analysed using MacClade (Maddison \& Maddison, 2000). A branch-and-bound search yielded six equally most parsimonious trees of 128 steps (consistency index 0,62 ; retention index 0,76 ). Of the total of 142 characters (all unordered and unweighted), 61 were phylogenetically informative within Mosasaurinae.

\section{Discussion}

The robust quadrate, the large temporal arcade and the stout mandible of $P$. saturator suggest this animal 


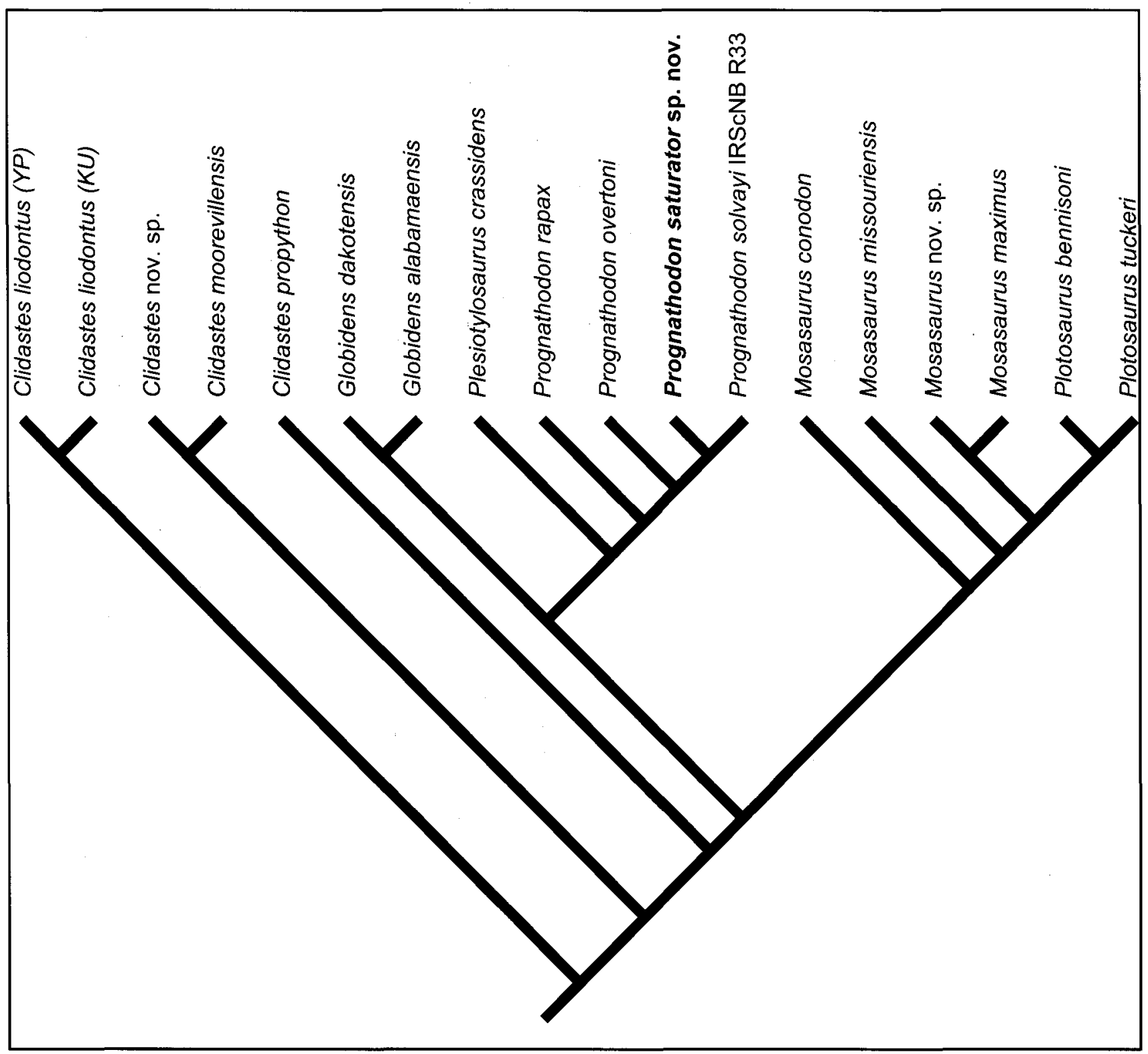

Fig. 4. Cladogram showing position of Prognathodon saturator sp. nov. within the Mosasaurinae depicting the preferred hypothesis of 6 equally parsimonious trees (length 128 steps, consistency index 0,62 , retention index 0,76 ).

could achieve bite forces unparallelled by any other mosasaur. The quadrates of the globidensine mosasaurs Globidens and Prognathodon both have fused suprastapedial and infrastapedial processes, a condition interpreted by Lingham-Soliar \& Nolf (1990) as an adaptation to counteract the strong vertical forces exerted on this bone during biting. Compared to the previously described quadrates of Globidensini, that of $P$ saturator is even more strongly built. Russell (1975) calculated the relative power of the jaw musculature in several mosasaurs using the temporal arcade length / overall skull length ratio. The durophagous Globidens dakotensis had the highest ratio of 0,27 , followed by $P$ overtoni at 0,22 . The much larger $P$. saturator has a ratio similar to $P$ overtoni (based on measurements on the reconstructed skull). The lever- age provided by the strong jaw musculature in combination with the relatively short and tall dentary would have resulted in an extremely powerful bite.

Having the most powerful jaws present in the Maastrichtian seas, and with examples of large marine turtle (Allopleuron) from the Maastricht area with pathologies suggesting healed bite marks (NHMM collections; a detailed description of these specimens is in preparation) available, it is not unlikely that the size range of possible prey items of $P$. saturator ranged up to these $2,90 \mathrm{~m}$ long turtles.

Various estimates of Prognathodon allometry (Russell, 1967; Lingham-Soliar \& Nolf, 1990; Kass, 1999) suggest that the length of the mandible represents $10-$ $14 \%$ of the body length. With a reconstructed mandible length of $140 \mathrm{~cm}$, and assuming a similar 


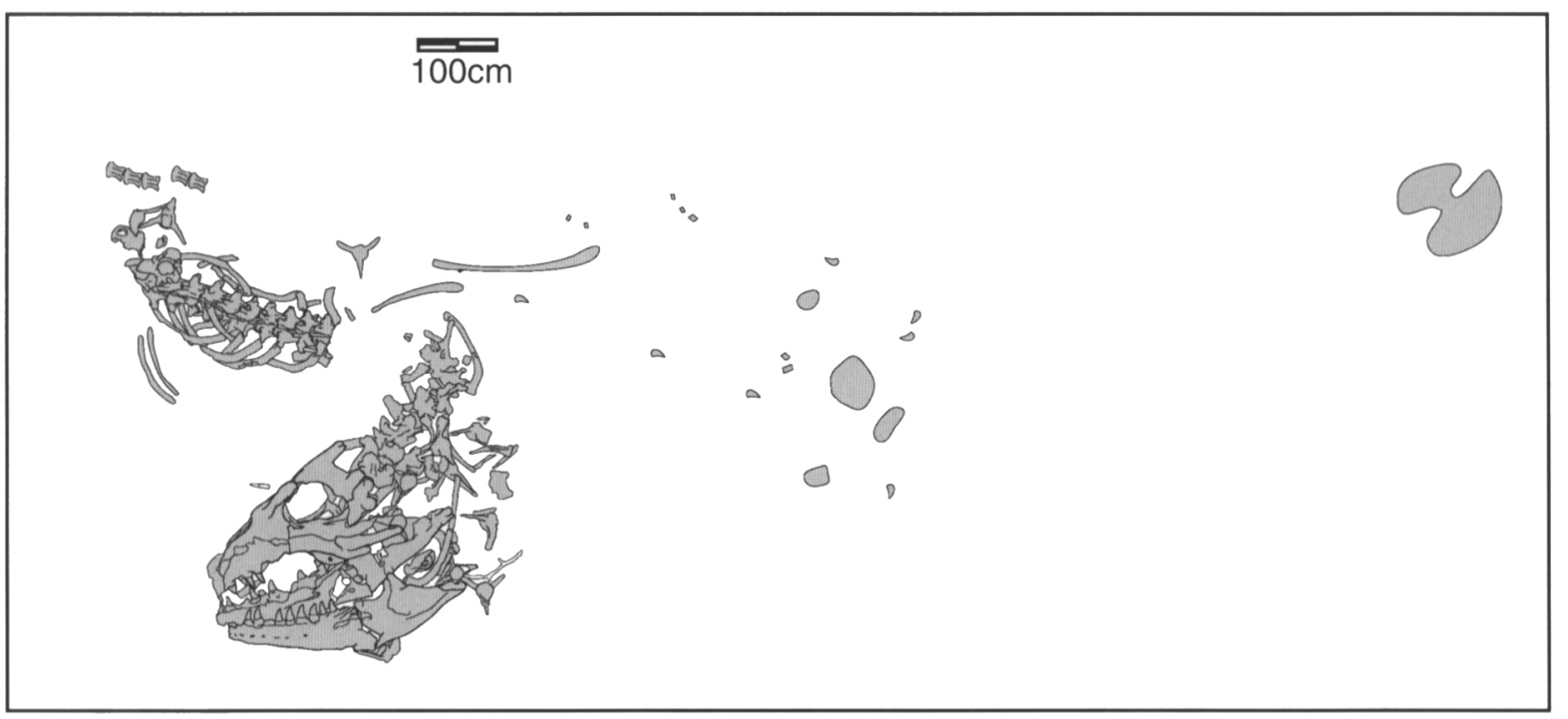

Fig. 5. Original position of skeletal remains at the quarry. Scale bar equals $100 \mathrm{~cm}$.

allometry as previously published estimates, the present specimen could have measured from 10 up to just over $14 \mathrm{~m}$. P. saturator probably did not reach the lengths attained by the largest individuals of Mosasaurus hoffmanni [for which lengths up to $17,6 \mathrm{~m}$ (Lingham-Soliar, 1995) have been calculated], but is still one of the largest marine reptiles known from the Maastrichtian type area, and certainly the most massively built species.

\section{Taphonomy}

The present specimen provides an interesting taphonomic case history. We consider age or disease to have been the most likely cause of death of this specimen, as marine predators capable of bringing down an animal of this size are unknown from the type Maastrichtian. The degree of articulation (Fig. 5) suggests that the animal reached the sea floor soon after its death, where it was scavenged by sharks prior to final burial. Indirect evidence of shark scavenging includes the presence of shed teeth of Squalicorax and Plicatoscyllium amongst the skeletal remains of the mosasaur. The teeth show no evidence of having been attacked by stomach acids, excluding the possibility that the teeth were in the mosasaur's stomach. The number of shark teeth recovered is too high to be explained by background abundance. Moreover, the fact that groups of teeth are all of the same size class and colour would also rule out such an interpretation. The various bite marks on the skeleton (Fig. 6) form direct evidence of shark scavenging. The few remaining portions of the appendicular skeleton were found disarticulated, which corresponds to previously reported patterns of scavenging on large marine reptiles (Kass, 1999; Schwimmer et al., 1997; Everhart,
1999). When the remaining parts of the skeleton were still connected with ligaments, the skeleton was partially covered with relatively coarse material, evidenced by current-aligned belemnites and caudal elements washed against the skull. The premaxilla and anteriormost portions of the dentaries, along with part of the tail, were lost to quarrying prior to the discovery of the specimen.

\section{Acknowledgements}

Funding for the recovery was provided by Natuurmonumenten, Mondriaan Foundation, the City of Maastricht, the Prins Bernhard Cultuurfonds and the

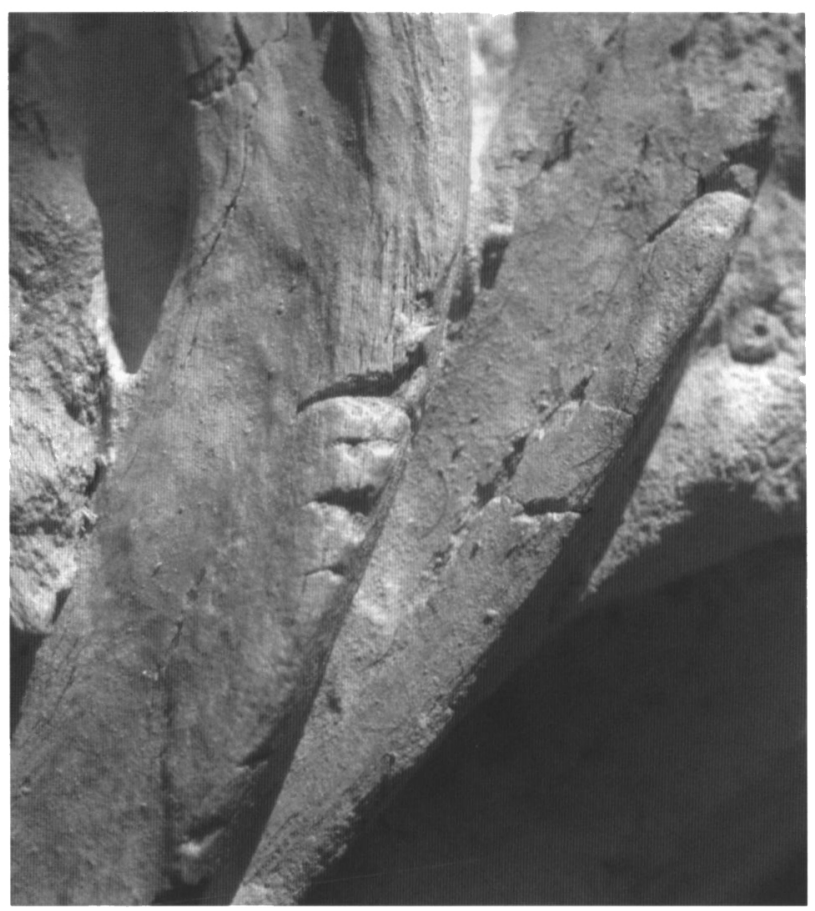

Fig. 6. Bite marks on ribs. 


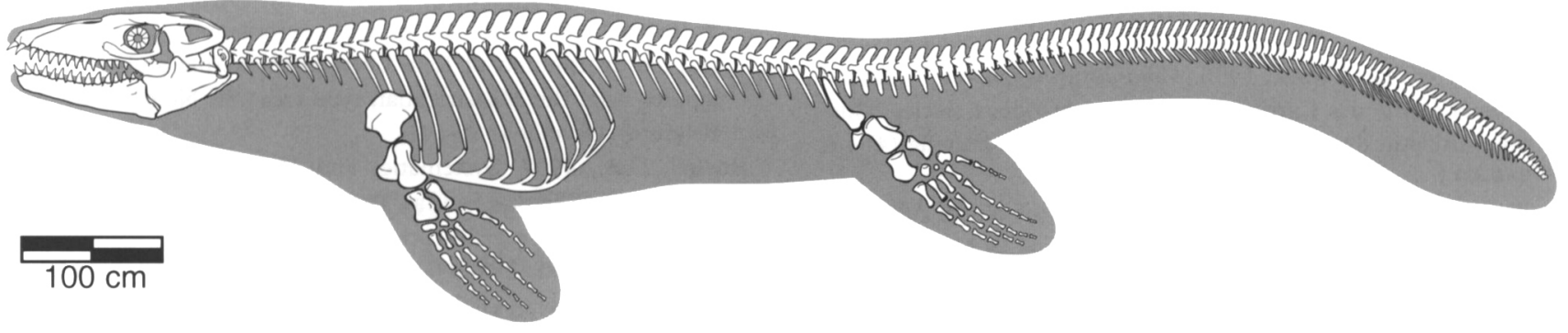

Fig. 7. Reconstruction of Prognathodon saturator $\mathrm{sp}$. nov. The premaxilla is reconstructed after Prognathodon solvayi (Rogier Trompert Medical Art, outline silhouette courtesy of Dan Varner).

Province of Limburg. We thank ENCI-Maastricht B.V. and Convoi Europe B.V. for support, the volunteers from the Nederlandse Geologische Vereniging, Afd. Limburg and the Vrije Universiteit Amsterdam for assistance in the field, and P. Bultynck and A. Dhondt for allowing access to the collections of the IRScNB (Brussels). Thanks are due to M. Everhart, J. Smit and D. Varner for helpful comments during preparation of the manuscript. Drawings of the specimen and the reconstruction (Fig. 7) were prepared for Rogier Trompert Medical Art, Maastricht, by J.-M. Luursema, M. Oberendorff, M. Spinder and R. Trompert. Dan Varner contributed the painting in Fig. 8.

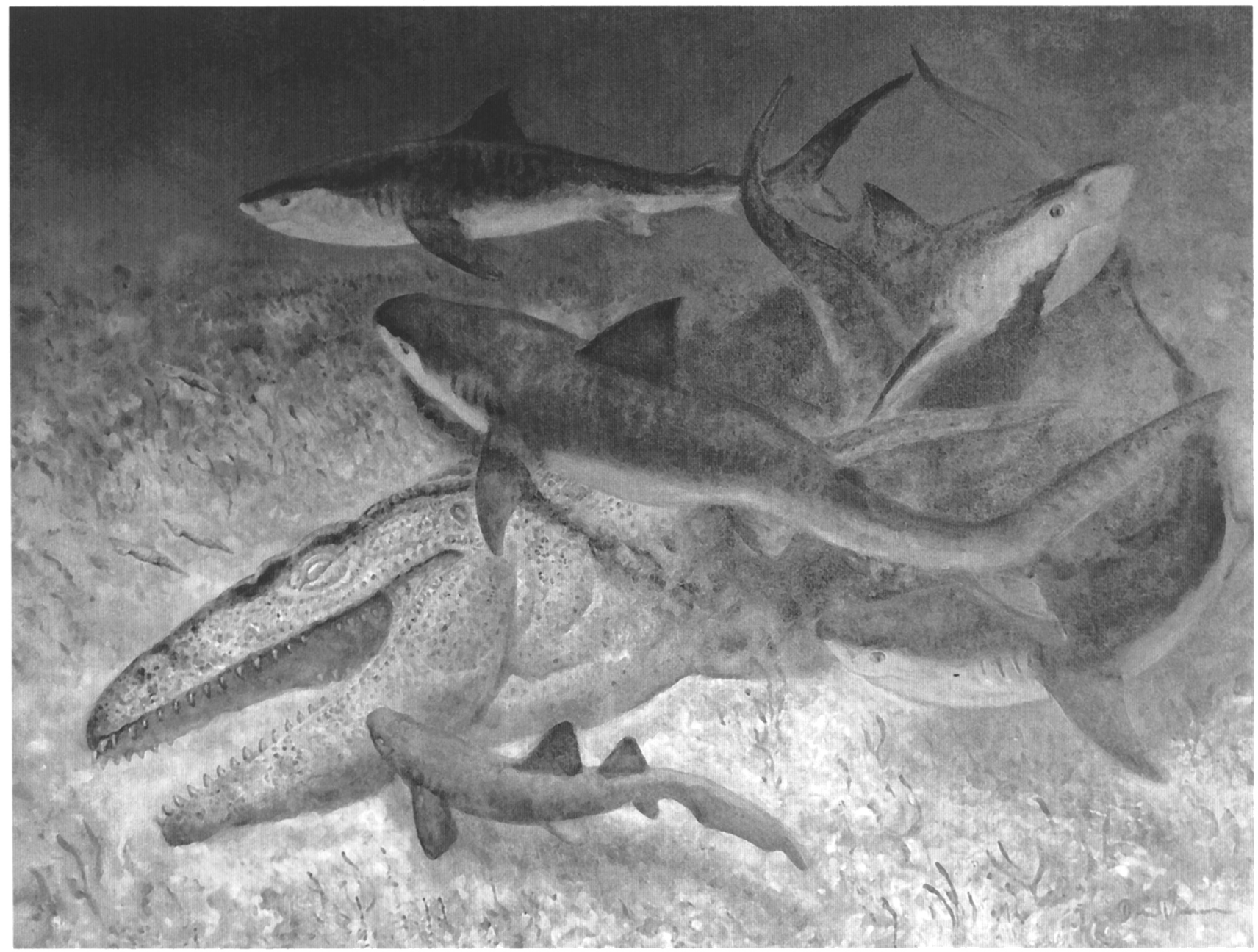

Fig. 8. Artist's impression of the carcass of Prognathodon saturator $\mathrm{sp}$. nov. being scavenged by Squalicorax and Plicatoscyllium sharks (Dan Varner). 


\section{References}

Bardet, N. \& Jagt, J.W.M., 1996. Mosasaurus hoffmanni, le "Grand Animal fossile des Carrières de Maestricht»: deux siècles d'histoire. Bulletin du Muséum national d'Histoire naturelle (4) 18 : 569-593.

Bell, G.L., Jr., 1997. A phylogenetic revision of North American and Adriatic Mosasauroidea. In: Callaway, J.M. \& Nicholls, E.L. (eds): Ancient Marine Reptiles. Academic Press (New York/London): 293-332.

Everhart, M.J., 1999. Evidence of feeding on mosasaurs by the Late Cretaceous lamniform shark, Cretoxyrhina mantelli. Journal of Vertebrate Paleontology 17(suppl. to 3): 43A-44A.

Kass, M.S., 1999. Prognathodon stadtmani: (Mosasauridae) A new species from the Mancos Shale (Lower Campanian) of Western Colorado. Utah Geological Survey Miscellaneous Publications 99-1: 275-294.

Kass, M.S. \& Smith, D., 2001. Preliminary report on new material for Prognathodon stadtmani (Mosasauridae). Journal of Vertebrate Paleontology 21 (suppl. to 3): 67A.

Kruytzer, E.M., 1957. De Mosasaurus van Bemelen. Mosasaurus hoffmanni Mantell. Natuurhistorisch Maandblad 46: 125-127.

Kuypers, M.M.M., Jagt, J.W.M., Peeters, H.H.G. \& De Graaf, D.Th., 1998. Laat-kretaceische mosasauriërs uit Luik-Limburg: Nieuwe vondsten leiden tot nieuwe inzichten. Publicaties van het Natuurhistorisch Genootschap in Limburg, 41: 5-48.

Lingham-Soliar, T., 1995. Anatomy and functional morphology of the largest marine reptile known, Mosasaurus hoffmanni (Mosasauridae, Reptilia) from the Upper Cretaceous, Upper Maastrichtian of the Netherlands. Philosophical Transactions of the Royal Society of London B347: 155-180.

Lingham-Soliar, T. \& Nolf, D., 1990. The mosasaur Prognathodon (Reptilia: Mosasauridae) from the Upper Cretaceous of Belgium. Bulletin de l'Institut royal des Sciences naturelles de Belgique, Sciences de la Terre 59 (1989): 137-190.

Maddison, D.R. \& Maddison, W.P., 2000. MacClade 4: Analysis of phylogeny and character evolution [Version 4.0]. Sinauer Associates (Sunderland, Massachusetts, 2001).
Mulder, E.W.A., Jagt, J.W.M., Kuypers, M.M.M., Peeters, H.H.G \& Rompen, P., 1998. Preliminary observations on the stratigraphic distribution of Late Cretaceous marine and terrestrial reptiles from the Maastrichtian type area (SE Netherlands, NE Belgium). Oryctos 1: 55-64.

Russell, D.A., 1967. Systematics and Morphology of American Mosasaurs (Reptilia, Sauria). Peabody Museum of Natural History, Bulletin 23: viii $+240 \mathrm{pp}$.

Russell, D.A., 1975. A New Species of Globidens from South Dakota, and a Review of Globidentine Mosasaurs. Fieldiana, Geology Memoirs 33: 235-256.

Schiøler, P., Brinkhuis, L., Roncaglia, L. \& Wilson, G.J. 1997. Dinoflagellate biostratigraphy and sequence stratigraphy of the Type Maastrichtian (Upper Cretaceous), ENCI quarry, The Netherlands. Marine Micropaleontology 31: 65-95.

Schwimmer, D.R., Stewart, J.D. \& Williams, G.D., 1997. Scavenging by Sharks of the Genus Squalicorax in the Late Cretaceous of North America. Palaios 12: 71-83.

Swofford, D.L., 2000. PAUP*: Phylogenetic Analysis Using Parsimony (*and Other Methods) [Version 4.0b8]. Sinauer Associates (Sunderland, Massachusetts).

Vonhof, H. \& Smit, J., 1996. Strontium-isotope stratigraphy of the type Maastrichtian and the Cretaceous-Tertiary boundary in the Maastricht area (SE Netherlands). In: Brinkhuis, H. \& Smit, J. (eds): The Geulhemmerberg Cretaceous/Tertiary boundary section (Maastrichtian type area, SE Netherlands). Geologie en Mijnbouw 75: 275-282.

Welles, S.P. \& Gregg, D.R., 1971. Late Cretaceous marine reptiles of New Zealand. Records of the Canterbury Museum 9:1-111.

\section{Institutional abbreviations:}

IRScNB: Institut Royal des Sciences Naturelles de Belgique, Brussels, Belgium

NHMM: Natuurhistorisch Museum Maastricht, The Netherlands 